\title{
Anesthesia of silver catfish with eugenol: time of induction, cortisol response and sensory analysis of fillet
}

\author{
Anestesia de jundiás com eugenol: tempo de indução, resposta ao cortisol e análise \\ sensorial do filé
}

\author{
Mauro Alves da Cunha ${ }^{I}$ Carla Cristina Zeppenfeld ${ }^{I}$ Luciano de Oliveira Garcia Vania Lucia Loro $^{\text {III }}$ \\ Milene Braga da Fonseca ${ }^{\text {III }}$ Tatiana Emanuelli ${ }^{\text {IV }}$ Ana Paula de Lima Veeck ${ }^{\text {IV }}$ Carlos Eduardo Copatti $^{\mathrm{V}}$ \\ Bernardo Baldisserotto ${ }^{*}$
}

\begin{abstract}
The aim of this study was to identify the time of anesthetic induction and recovery of silver catfish (Rhamdia quelen) exposed to eugenol. It was also determined the efficacy of the anesthetic as a stress reducing agent and performed a sensory analysis of the fillets from fish exposed to this substance. The silver catfish were exposed to air for 1min to carry out biometry, and blood was collected at 0,1 and 4 hours later. Eugenol can be used in the range of 20-50mg $L^{-1}$ for anesthetic induction in silver catfish, and recovery time from anesthesia was not affected by eugenol concentration. The control group showed significantly higher cortisol levels 4 hours after biometry than at time zero. Fish anesthetized with eugenol (50mg $\left.\mathrm{L}^{-1}\right)$ presented significantly lower plasma cortisol levels than control fish at the same time. These data indicate that eugenol inhibits the rise of cortisol in the blood. The sensory analysis test demonstrated that eugenol modifies the flavor of the fillet and therefore is contra-indicated for anesthetization of silver catfish that are intended for human consumption.
\end{abstract}

Key words: clove oil, Rhamdia quelen, sedation, stress, taste. RESUMO

O objetivo deste estudo foi identificar o tempo de indução e recuperação anestésica de jundiás (Rhamdia quelen) expostos ao eugenol, bem como a eficácia desse anestésico na inibição do estresse e realizar análise sensorial dos filés dos peixes expostos a essa substância. Os jundiás foram expostos ao ar por um minuto para realização da biometria, e o sangue foi coletado zero, uma e quatro horas depois. O eugenol pode ser usado na faixa de 20-50mg $L^{-1}$ para a indução da anestesia em jundiás, e o tempo de recuperação da anestesia não foi afetado pela concentração do eugenol. O grupo de controle mostrou níveis significativamente mais elevados do cortisol quatro horas após a biometria que no tempo zero. Os peixes anestesiados com eugenol (50 $\left.\mathrm{mg}^{-1}\right)$ apresentaram níveis significativamente mais baixos do cortisol plasmático do que peixes do grupo de controle do mesmo tempo. Esses dados indicam que o eugenol inibe o aumento do cortisol no sangue. $O$ teste sensorial demonstrou que o eugenol modifica o sabor dos filés e consequentemente é contra-indicado para a anestesia do jundiá quando o filé for destinado ao consumo humano.

Palavras-chave: óleo de cravo, Rhamdia quelen, sedação, estresse, palatabilidade.

\section{INTRODUCTION}

Currently, procedures for managing and manipulating silver catfish (Rhamdia quelen) do not involve the use of anesthetics. However, due to increased interest in product quality, the use of sedatives is occasionally necessary to facilitate management and to reduce fish stress during handling. Stress induces cortisol secretion by the interrenal tissue, and this hormone causes various secondary stress responses, including increased glucose and lactate plasma levels (ROTLLANT et al., 2001; SKJERVOLD et al., 2001). Increased plasma levels of

'Departamento de Fisiologia e Farmacologia, Universidade Federal de Santa Maria (UFSM), 97105-900, Santa Maria, RS, Brasil. E-mail: bernardo@smail.ufsm.br. *Autor para correspondência.

"Instituto de Oceanografia, Estação Marinha de Aquacultura, Universidade Federal do Rio Grande (FURG), Rio Grande, RS, Brasil. "IIDepartamento de Química, UFSM, Santa Maria, RS, Brasil

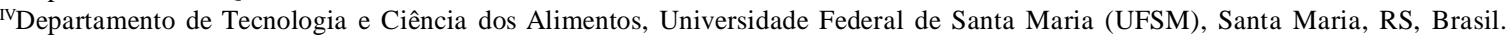

`Departamento de Ciências da Saúde, Universidade de Cruz Alta (UNICRUZ), Cruz Alta, RS, Brasil. 
these parameters is an indication of glycogen mobilization and is associated with poor quality and rigidity of fish fillets (SKJERVOLD et al., 1999, 2001). High levels of plasma cortisol can also induce a decrease in the immunologic capacity of salmon (Oncorhynchus tshawytscha) (PICKERING \& POTTINGER 1989) and channel catfish (Ictalurus punctatus) (DAVIS et al., 2002, 2003). Certain anesthetics, as metomidate (OLSEN et al., 1995), eugenol and isoeugenol (Aqui-S) (IVERSEN et al., 2003) can reduce or obstruct hypothalamus-hypophysis-interrenal axis activation, resulting in lower cortisol discharge (ROTLLANT et al., 2001; SKJERVOLD et al., 2001).

Clove oil is an anesthetic derived from distillation of plant parts from the Eugenia genus (Eugenia caryophyllata and E. aromatica) (LEE \& SHIBAMOTO, 2001), and the active ingredient is eugenol (makes up to $90-95 \%$ of the clove oil), which functions as a depressor of the Central Nervous System (ANDERSON et al., 1997). Moreover, clove oil has been indicated as an alternative to traditional anesthetics as metomidate, quinaldine, and tricaine methanesulphonate because it is a natural oil and safe to use (SLADKY et al., 2001). The clove oil concentrations necessary for anesthesia induction vary by species. In channel catfish (Ictalurus punctatus), bluegill (Lepomis macrochirus) (STEHLY \& GINGERICH 1999), Atlantic salmon (Salmo salar) (IVERSEN et al., 2003), rainbow trout (Oncorhynchus mikiss) (KEENE et al., 1998), black pacu (Piaractus brachypomus) (SLADKY et al., 2001), Chinook salmon (Oncorhynchus thsawytscha) (CHO \& HEATH 2000) and largemouth bass (Micropterus salmoides) (COOKE et al., 2004) clove oil is effective at concentrations of $10-50 \mathrm{mg} \mathrm{L}^{-1}$.

The aim of this study was to determine the optimal eugenol concentration for silver catfish anesthesia and to evaluate the time of anesthetic induction and recovery from anesthesia. Furthermore, it was examined the effect of eugenol on plasma cortisol levels of silver catfish exposed to handling stress and the sensory characteristics of the resulting fillets.

\section{MATERIAL AND METHODS}

Animals

Juvenile silver catfish were purchased from a fish culture and transported to the laboratory, where they were maintained for two weeks in continuously aerated $250 \mathrm{~L}$ tanks, $21 \pm 1^{\circ} \mathrm{C}$, $\mathrm{pH}$ 6.6-7.0, dissolved oxygen levels $5.8-7.2 \mathrm{mg} \mathrm{L}^{-1}$. Juveniles were fasted for $24 \mathrm{~h}$ prior to experiments.
Anesthesia induction and recovery

Juvenile fish $(2.14 \pm 0.01 \mathrm{~g}$ and $7.0 \pm 0.1 \mathrm{~cm})$ were transferred to aquaria containing $1 \mathrm{~L}$ of water and eugenol (Eugenol, Odontofarma ${ }^{\circledR}$, Porto Alegre, Brazil) at concentrations (in $\mathrm{mg} \mathrm{L}^{-1}$ ) of 5, 10, 20, 30, 40, 50, 60 or 70 , first diluted in ethanol (1:20). Control experiments were performed using aquaria containing ethanol alone at the same concentration as used to the dilution of the highest eugenol concentration. To evaluate the time required for anesthesia induction, 20 juveniles were used for each concentration tested, and each juvenile was used only once, according to SCHOETTGER \& JULIN (1967). The maximum observation time was 30min. After induction, juveniles were transferred to anesthetic-free aquaria to measure anesthesia recovery time.

Measurements of plasma cortisol

Juvenile fish $(194.89 \pm 12.5 \mathrm{~g}$ and $26.0 \pm 0.6 \mathrm{~cm})$ were divided into two treatment groups: eugenol first diluted in ethanol (1:20) $\left(50 \mathrm{mg} \mathrm{L}^{-1}\right)$ (this concentration was used because is the lower concentration to obtain anesthesia within a short period of time, around $111 \mathrm{~s}$, see results) or control (without anesthetic). Anesthesia was carried out in an aquarium containing $5 \mathrm{~L}$ of water (1-2min), and biometry (weight and length measurements - time of air exposure: 1min) was performed. Following biometry, blood was collected from the caudal vein of 12 juveniles (time 0 ). The remaining anesthetized juveniles were placed in two $250 \mathrm{~L}$ tanks and blood samples of 12 fish from one tank were collected $1 \mathrm{~h}$ later and from 12 fish from another tank $4 \mathrm{~h}$ after anesthesia. The control group was subjected to the same procedures as the test group except by the exposure to eugenol, and the fish were held while the biometric measurements were taken. Blood was collected using a Hamilton syringe, transferred to $2 \mathrm{~mL}$ plastic tubes and later centrifuged $3000 \mathrm{xg}$ to separate plasma, which was kept under constant refrigeration. Plasma cortisol level was measured using a commercially available solid phase competitive chemoluminescent enzyme inmunoassay kit (Immulite 2000) (Diagnostic Products Corporation, Los Angeles CA, USA). The specificity of the test was evaluated by comparing the parallelism between the standard curve and serial dilutions in PBS ( $\mathrm{pH}$ 7.4) of the plasma samples. No differences were observed between human and fish samples. The standard curve, constructed with human samples ran parallel to that obtained using serial dilutions of silver catfish plasma. A high positive correlation $\left(r^{2}=0.9725\right)$ was obtained between curves. The coefficient of variation observed from fish ranged from 9 to $12 \%$. Fish from which blood 
was collected at time 0 were euthanized by severing the spinal cord immediately after blood collection. Fillets were obtained from these fish, which were later used for sensory analysis.

\section{Sensory analysis}

To determine whether there was a difference in the taste and odor attributes between the fillets from fish submitted to eugenol treatment $\left(50 \mathrm{mg} \mathrm{L}^{-1}, 1-2 \mathrm{~min}\right.$, see previous section "Measurements of plasma cortisol") and control fish (no eugenol) the difference from a standard method described by COSTELL (2002) was used. Fillets were cooked in a microwave oven $\left(20 \mathrm{~g}^{1 \mathrm{~min}^{-1}}\right)$ and evaluated by 26 untrained judges. The degree of taste and odor difference from control was measured on a seven-point scale, where $1=$ extremely better than control; $2=$ moderately better than control; $3=$ slightly better than control; $4=$ not different from control; $5=$ slightly worse than control; $6=$ moderately worse than control; $7=$ extremely worse than control. Samples were coded by random numbers and presentation of the samples included a hidden control. Sensory scores were obtained for the treated sample and for the control sample.

\section{Statistical analysis}

All data were submitted to a Levene test to verify the homogeneity of variance. Variance was found to be equivalent between different groups, so analysis of plasma cortisol levels were carried out using twoway ANOVA, followed by Tukey post hoc test. Data from sensory analysis were analyzed using the MannWhitney $\mathrm{U}$ test. The time of anesthetic recovery data were analyzed using the Kruskal-Wallis and MannWhitney tests. Comparisons of time to anesthesia induction to stage 4 with $50 \mathrm{mg} \mathrm{L}^{-1}$ eugenol in silver catfish of two different sizes were analyzed using the Student T test. STATISTICA (version 5.1) was used for analyses and significance was set at a level of $95 \%$ $(\mathrm{P}<0.05)$.

\section{RESULTS}

Fish exposed to 5 and $10 \mathrm{mg} \mathrm{L}^{-1}$ eugenol showed no evidence of anesthesia during the 30min evaluation period. In juveniles exposed to higher concentrations of eugenol, increasing eugenol concentration proportionally decreased induction time for 2 to 4 stages of anesthesia (Figure 1). No mortality was found during anesthesia induction and recovery between 20 and $50 \mathrm{mg} \mathrm{L}^{-1}$ eugenol administration. However, at 60 and $70 \mathrm{mg} \mathrm{L}^{-1}$, some fish reached stage 5 (respiratory movements ceased) and consequently mortality increased to $20 \%$ and $65 \%$, respectively. Ethanol alone showed no anesthetic effect.

No significant difference was found in the recovery time at the different concentrations of eugenol tested (206.4-260.2s). Likewise, there was no significant difference between the latency to anesthesia induction and recovery in juveniles of different sizes induced to stage 4 with $50 \mathrm{mg} \mathrm{L}^{-1}$ eugenol (time for anesthesia induction to stage $4-2 \mathrm{~g}: 206.4 \pm 22.5 \mathrm{~s}$ and $177 \mathrm{~g}$ : 243.2 $\pm 19.4 \mathrm{~s})$.

The control group showed significantly higher cortisol levels $4 \mathrm{~h}$ after biometry than at time zero. Silver catfish anesthetized with eugenol showed significantly lower plasma cortisol levels than fish from the control group at the same time $(\mathrm{P}<0.05)$ (Figure 2).

The median sensory score (interquartile range) of the odor of fillets obtained from silver catfish anesthetized with eugenol was 4 (3-5), like that from control fish 4 (3-5). However, the median taste score (interquartile range) of fillets from fish anesthetized with eugenol was significantly higher 6 (6-7) than that from control fish 4 (3-4) $(\mathrm{P}<0.05)$, indicating that the taste of filets from fish exposed to eugenol was considered worse than that from control fish (slightly to moderately).

\section{DISCUSSION}

Anesthesia induction and recovery In this study, eugenol concentrations above $20 \mathrm{mg} \mathrm{L}^{-1}$ induced stage 4 of anesthesia in silver catfish within $15 \mathrm{~min}$, while lower concentrations had no anesthetic effect within 30min. A positive effect was determined by a rapid induction to stage 4 of anesthesia and a lack of harm to the fish at a concentration of $50 \mathrm{mg} \mathrm{L}^{-1}$. At this concentration, stage 4 anesthesia was reached in $111 \mathrm{~s}$ and death among the tested animals did not occur. Therefore, this concentration of eugenol was indicated for induction to stage 4 of anesthesia. The effect of clove oil varies according to the species, but 20-50 $\mathrm{mg} \mathrm{L}^{-1}$ induced stage 4 of anesthesia within 120-360s in juvenile Chinook salmon (CHO \& HEATH 2000), rainbow trout (KEENE et al., 1998), black pacu (SLADKY et al., 2001), and Atlantic salmon (IVERSEN et al., 2003).

The size of fish appears to be positively correlated with the latency to anesthesia induction (OLSEN et al., 1995), but no significant difference in the time to anesthesia induction to stage 4 with eugenol $50 \mathrm{mg} \mathrm{L}^{-1}$ was found relative to fish size for silver catfish in this study. 


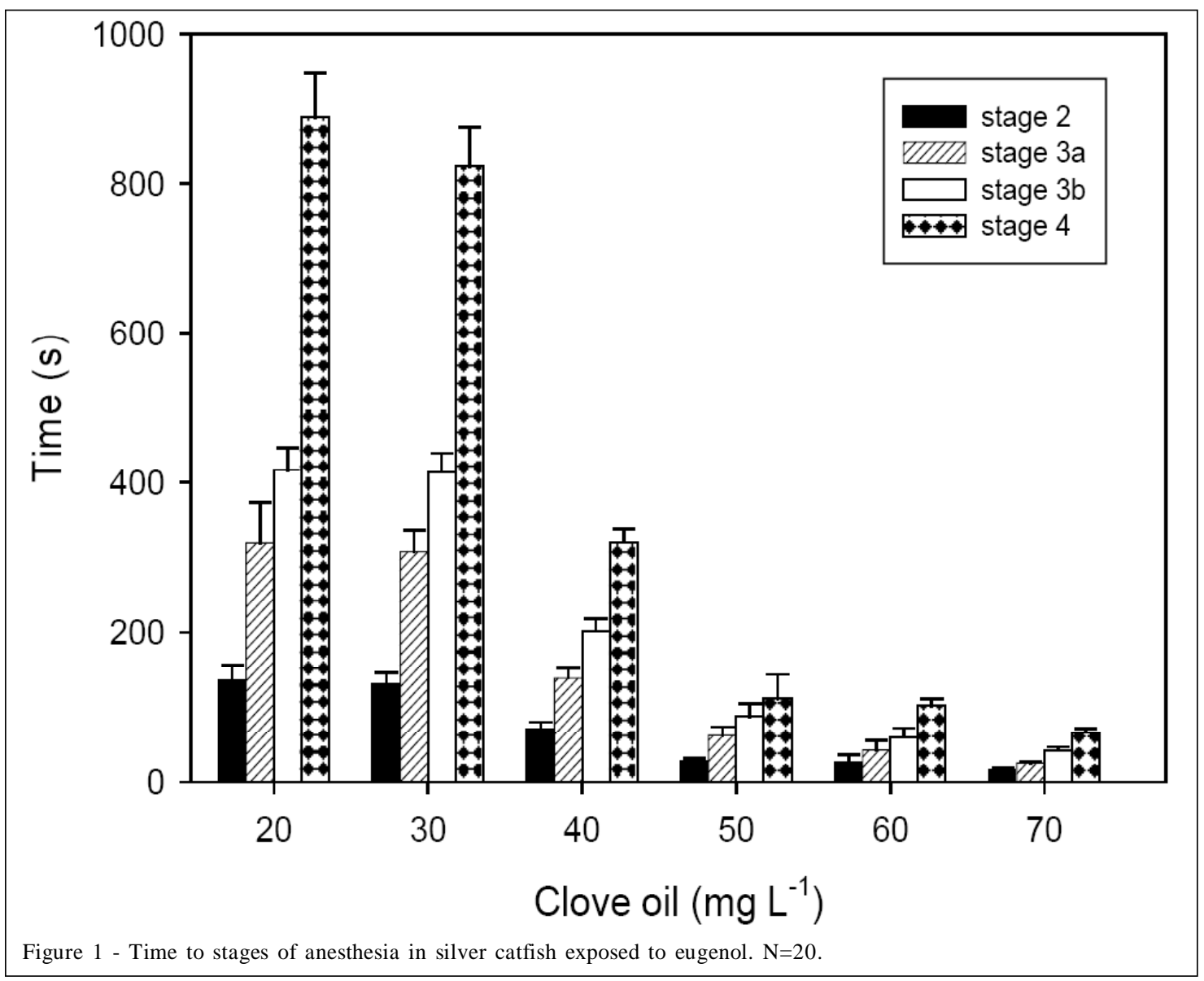

Evaluation of plasma cortisol

Clove oil at concentrations higher than $20 \mathrm{mg} \mathrm{L}^{-1}$ prevented plasma cortisol elevation above resting levels in Atlantic salmon, but its mechanism of action is not known. However, it is reasonable to presume that the drug disrupts transmission of sensory information to the hypothalamus (IVERSEN et al., 2003). One of the main fish responses to adverse situations is the production of catecholamines and corticosteroids, which are responsible for physiological and biochemical changes and are usually characterized as stress responses. Cortisol levels in non stressed fish vary from 5 to $51 \mathrm{ng} \mathrm{mL}^{-1}$ and after acute stress from 30 to $309 \mathrm{ng} \mathrm{mL}^{-1}$ (DAVIDSON et al., 2000). The resting cortisol level in non stressed silver catfish is $23.80 \pm 5.45 \mathrm{ng} \mathrm{mL}^{-1}$, which is significantly lower than the level of chronically stressed fish $(55.23 \pm 11.44 \mathrm{ng}$ $\mathrm{mL}^{-1}$ ) (BARCELLOS et al., 2006), and similar to the values obtained in the control fish (20-25ng mL-1) in the first two measurements. The increase of plasma cortisol values in control fish $4 \mathrm{~h}$ after biometry was also observed by CUNHA et al. (2010) in an experiment using the same handling methodology. Cortisol secretion is dependent on the severity and value of the stressor applied (SUMPTER et al., 1985). Rainbow trout exposed to air for 30s showed increased plasma cortisol levels 30min later (SLOMAN et al., 2001). In chronically stressed silver catfish the cortisol peak occurs $1 \mathrm{~h}$ after exposure to a new stress factor (BARCELLOS et al., 2006). In our study at time zero the levels of plasma cortisol in control fish were already significantly higher than those anesthetized with eugenol, and a further increase (compared to time zero) occurred $4 \mathrm{~h}$ after air exposure and handling. However, silver catfish anesthetized with eugenol presented significantly lower plasma cortisol levels than control fish at all analyzed times, which supports the hypothesis that this anesthetic prevents an increase of cortisol in the plasma at the moment of handling and air exposure. A similar result was obtained by CUNHA et al. (2010) using the essential oil of Lippia alba as anesthetic.

Sensory analysis

The sensory analysis is relevant in this study because it evaluates fish quality in the same way that the consumer would perceive fish quality. 


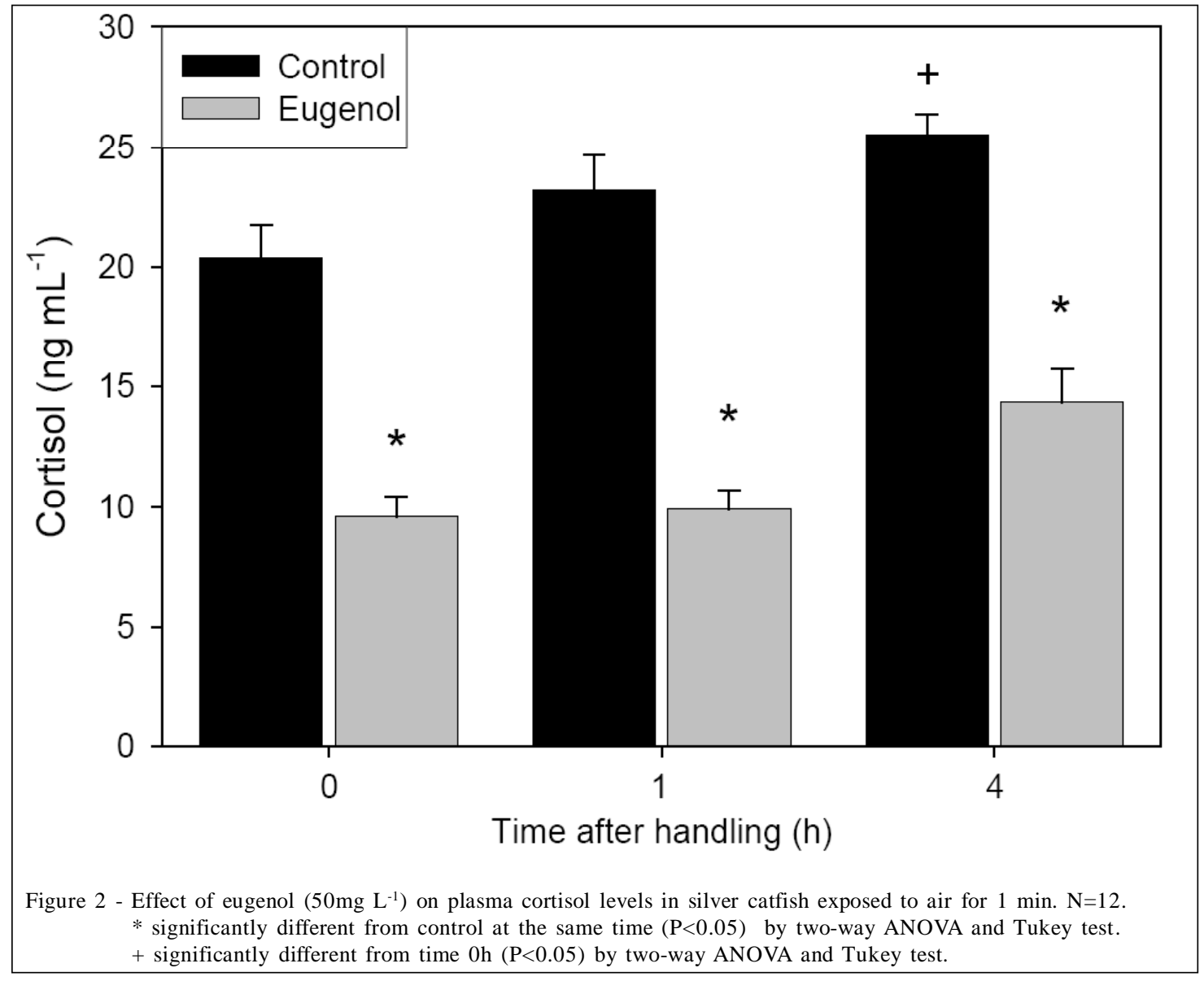

Recent studies propose some method of anesthesia for fish slaughter practice (SAVENIJE et al., 2002; LINES et al., 2003; MATOS et al., 2010). AQUI-S ${ }^{\mathrm{TM}}$ is a fish anesthetic/sedative approved for use in several countries, and its active ingredient, isoeugenol, is approved for human consumption in the U.S. when used as a food flavoring. AQUI-S ${ }^{\mathrm{TM}}$ has been developed as an anesthetic that may be used on food-fish with no withdrawal period. Isoeugenol residues were detected in rainbow trout fillets after exposure to AQUI-S ${ }^{\mathrm{TM}}$ (MEINERTZ et al., 2006), but this compound is not known to produce adverse taste responses. Recently, it was demonstrated that exposure of Solea senegalensis to clove oil can assure a high quality product for the market. Moreover, the authors concluded that the results can also be applied to other species used in aquaculture as a method to assure high quality fish for human consumption (RIBAS et al., 2007). However, they did not evaluate the taste of their fish. In the present study, sensory analysis demonstrated that anesthesia with clove oil adversely affects the taste of silver catfish fillets. This change probably occurred due to the strong flavoring capacity of clove oil, and suggests that some residues of the oil remain in the fish muscle. The Food and Drug Administration (FDA) does not approve clove oil as an anesthetic in fish for human consumption because of safety concerns (US FDA 2007). Aqui-S (or isoeugenol) is also not approved yet for use in fish (US FDA 2010) However, clove oil and eugenol have been widely used as a flavoring and antimicrobial agent in the food industry (VELLUTI et al., 2003; JECFA2006). Although clove oil and many of its components are considered to be "generally recognized as safe" (GRAS) substances for use as food additives by the United States FDA (1978), there is some evidence of carcinogenicity for eugenol and methyleugenol (US FDA 2007). The joined results suggest that due to sensory concerns eugenol is contra-indicated for anesthesia at the moment of slaughter if the fish is intended to be used for human consumption.

Eugenol is an effective anesthetic for silver catfish and can be used at $20-50 \mathrm{mg} \mathrm{L}^{-1}$ without problems for the fish or the handlers, but care must be taken if the fish is to be used for consumption after anesthesia because eugenol leaves an unpleasant taste in the fillet. 


\section{ACKNOWLEDGEMENT}

This research was supported by Conselho Nacional de Desenvolvimento Científico e Tecnológico (CNPq). B. Baldisserotto received a $\mathrm{CNPq}$ research grant.

\section{REFERENCES}

ANDERSON, W.G. et al. The use of clove oil as an anesthetic for rainbow trout and its effects on swimming performance. North American Journal of Fisheries Management, v.17, p. 301-307, 1997.

BARCELLOS, L.J.G. et al. Previous chronic stress does not alter the cortisol response to an additional acute stressor in jundiá (Rhamdia quelen, Quoy and Gaimard) fingerlings. Aquaculture, v.253, p.317321, 2006. Disponível em: <http://docushare.sf.adfg.state.ak.us/ docushare/dsweb/Get/Document-14938/anderson+1997.pdf>. Acesso em: 25 ago. 2010. doi:10.1016/j.aquaculture.2005.05.035

CHO, G.K.; HEATH, D.D. Comparison of tricaine methanesulphonate (MS222) and clove oil anaesthesia effects on the physiology of juvenile Chinook salmon Oncorhynchus tshawytscha (Walbaum). Aquaculture Research, v.31, p.537546, 2000. Disponível em: <http://onlinelibrary.wiley.com/doi/ 10.1046/j.1365-2109.2000.00478.x/pdf>. Acesso em: 26 ago. 2010. doi: 10.1046/j.1365-2109.2000.00478.x

COOKE, S.J. et al. Behavioral and physiological assessment of low concentrations of clove oil anaesthetic for handling and transporting largemouth bass (Micropterus salmoides). Aquaculture, v.239, p.509-529, 2004. Disponível em: < h t t p://fishlab.nres.ui uc.edu/Documents/ Aquaculture\%202004.pdf $>$. Acesso em: 26 ago. 2010. doi:10.1016/j.aquaculture.2004.06.028.

COSTELL, E. A comparison of sensory methods in quality control. Food quality and preference, v.13, p.341-353, 2002. Disponível em: <http://www.sciencedirect.com/ science?_ob=ArticleURL\&_udi=B6T6T-45C1S7N$1 \& \_u s e r=687358 \& \_c o v e r D a t e=09 \% 2 F 30 \% 2 F 2002 \& \_r d o c=1 \& \_f m t=$ high\&_orig $=$ search\&_sort $=d \&$ docanchor $=\& v i e w=c \&$ search StrId $=1442265856 \& \_$rerunOrigin $=$google $\& \_a c c t=C 000037899 \& \_v$ ersion $=1 \&$ \&urlVersion $=0 \& \_u s e r i d=687358 \& \mathrm{md} 5=6 \mathrm{fd} 93 \mathrm{~d} 701 \mathrm{e}$ 3f5c4595a2515cb594e06e>. Acesso em: 26 ago. 2010. doi:10.1016/S0950-3293(02)00020-4.

CUNHA, M.A. et al. Essential oil of Lippia alba: a new anesthetic for silver catfish, Rhamdia quelen. Aquaculture, v.306, p.403406, 2010. Disponível em: <http://www.sciencedirect.com/ science?_ob=ArticleURL\&_udi=B6T4D-50B B 58R$3 \&$ _ u s e r $=687358 \&$ _ c o v e r D a t e $=$ $08 \% 2 \mathrm{~F} 15 \% 2 \mathrm{~F} 2010 \&$ r d o c $=1 \&$ \& $\mathrm{fm}$ $\mathrm{t}=\mathrm{high} \&$ _orig $=$ search\&_sort $=\bar{d}_{\&} \&_{-}$docanchor $=\&$ vie $\mathrm{w}=\mathrm{c} \&$ _searchStrId=1442273436\&_rerunOrigin $=\mathrm{g}_{\mathrm{o}} \mathrm{og} \mathrm{e} \&_{-} \mathrm{acct}=\mathrm{C} 000037899 \&_{-}$version $=$ $1 \&$ _ urlversion $=0 \&$ _ userid $=687358 \& \mathrm{md} 5=$ 459b9fd9c28a125e4e111d0a89aec690>. Acesso em: 26 ago. 2010. doi:10.1016/j.aquaculture.2010.06.014.

DAVIDSON, G.W. et al. Physiological responses of rainbow trout Oncorhynchus mykiss to crowding and anesthesia with Aqui- $\mathrm{S}^{\mathrm{tm}}$. Journal World Aquaculture Society, v.31, p.105114, 2000. Disponível em: <http://onlinelibrary.wiley.com/doi/ 10.1111/j.1749-7345.2000.tb00704.x/pdf >. Acesso em: 26 ago. 2010. doi:10.1111/j.1749-7345.2000.tb00704.x.
DAVIS, K.B. et al. Effect of handling stress on susceptibility of channel catfish Ictalurus punctatus to Ichthyophthirius multifiliis and channel catfish virus infection. Aquaculture, v.214, p.5566, 2002. Disponível em: <http://www.sciencedirect.com/ science?_ob=ArticleURL\&_udi=B 6T 4D-46 W KY 47 $3 \&$ u ser $=687358 \&$ \& coverDate $=11 \% 2$ F $15 \% 2$ F 2 $002 \&$ \&doc=1\&_fmt $=$ high\&_orig=search\&_so $\mathrm{rt}=\mathrm{d} \&$ docanchor $=\& \mathrm{view}=\mathrm{c} \&$ _se archStrId $=14$ $42286317 \&$ \& rerunOrigin $=$ google \&_acct $=\mathrm{C}$ $000037899 \&$ \&ersion $=1 \&$ \&urlVersion $=0 \&$ \&userid $=$ $687358 \& \mathrm{md} 5=\mathrm{b} 7 \mathrm{~b} 84 \mathrm{ad} 73 \mathrm{f} 0802 \mathrm{c} 698797 \mathrm{~d} 65 \mathrm{~b} 21 \mathrm{c} 12 \mathrm{fa}>$. Acesso em: 26 ago. 2010. doi:10.1016/S0044-8486(02)00362-9.

DAVIS, K.B. et al. Effect of dietary cortisol on resistance of channel catfish to infection by Ichthyophthirius multifiliis and channel catfish virus disease. Aquaculture, v.218, p.121130, 2003. Disponivel em: <http://www.sciencedirect.com/ s c i ence?_ob = A r t i c le URL \&_udi=B 6 T 4 D 47PPC7X2\&_user $=687358 \&$ _coverDate $=03 \% 2 \mathrm{~F} 27 \% 2 \mathrm{~F} 2003 \&$ alid $=1442293058 \& \_r d o c=2 \& \_f m t=h i g h \& \_o r i g=s e a r c h \& \_c d i$ $=4972 \& \_s o r t=r \& \_d o c a n c h o r=\& v i e w=c \& \_c t=13 \& \_a c c t=C 0000378$ $99 \& \_v e r s i o n=1 \& \_u r l$ Version $=0$ \&_userid $=687358 \& \mathrm{md} 5=37 \mathrm{fb} 4 \mathrm{~d} 7891 \mathrm{a}$ 0536da7318ae853ac4fcf $>$. Acesso em: 26 ago.2010. doi: $10.1016 / \mathrm{S} 0044-8486(02) 00630-0$

IVERSEN, M. et al. The efficacy of metomidate, clove oil, Aqui-S and Benzoak as anaesthetics in Atlantic salmon (Salmo salar L.) smolts, and their potential stressreducing capacity. Aquaculture, v.221, p.549-566, 2003. Disponível em: <http://www.sciencedirect.com/ science?_ob=ArticleURL\&_udi=B 6T 4D-4834JFY$4 \& \_u s e r=687358 \&$ _coverDate $=05 \% 2 \mathrm{~F} 01 \% 2 \mathrm{~F} 2003 \& \_$rdoc $=1 \&$ $\mathrm{fmt}=$ high \&_orig $=$ search \&_sort $=\mathrm{d} \& \_$docanchor $=\& \mathrm{view}=\mathrm{c} \& \_$ searchStrId $=1442308772 \&$ _rerunOrigin $=$ google \&_acct $=$ C000 037899 \&_version $=1 \&$ \&urlVersion $=0$ \&_userid $=687358 \& \mathrm{md} 5$ $=\mathrm{d} 51 \mathrm{f} 961 \mathrm{f} 47 \mathrm{cb} 919166 \mathrm{f} 42360 \mathrm{fa} 3 \mathrm{~b} 1 \mathrm{a} 06>$. Acesso em: 26 ago. 2010. doi:10.1016/S0044-8486(03)00111-X.

JECFA, 2006. Summary of evaluations performed by the Joint FAO/WHO expert committee on food dditives. JECFA no. 1529. Eugenol. Jan 31, 2006. Available from: <http://www.inchem.org/ documents/jecfa/jeceval/jec_841.htm>. Online. Acesso em: 8 abr. 2008.

KEENE, J.L. et al. The efficacy of clove oil as an anaesthetic for rainbow trout, Onchorhynchus mykiss (Walbaum). Aquaculture Research, v.29, p.89-101, 1998. Disponível em: <http://onlinelibrary.wiley.com/doi/10.1046/j.13652109.1998.00927.x/pdf >. Acesso em: 26 ago. 2010. doi: 10.1111/j.1365-2109.1998.tb01113.x.

LEE, K.G., SHIBAMOTO, T. Antioxidant property of aroma extract isolated from clove buds (Syzygium aromaticum L.). Food Chemistry, v.74, p.443-448, 2001. Disponível em: <http://www.sciencedirect.com/ science?_ob=ArticleURL\&_udi=B6T6R-43T7 THV$7 \&$ \&user $=687358 \&$ _coverDate $=09 \% 2 \mathrm{~F} 30 \% 2 \mathrm{~F} 2001 \&$ \& rdoc $=1 \&$ _fmt=high\&_orig=search\&_sort=d\&_docanchor $=\&$ view $=c \&$ _ searchStrId $=1442314464 \& \_$rerunOrigin $=$google $\& \_$acct $=C 000037899$ \&_version=1\&_urlVersion=0\&_userid $=687358 \& \mathrm{md} 5=9 \mathrm{~b} 4 \mathrm{e} 586420$ baaeb07141613f5ac58a22>. Acesso em: 26 ago. 2010. doi: 10.1016/S0308-8146(01)00161-3.

LINES, J.A. et al. Electric stunning: a humane slaughter method for trout. Aquacultural Engineering, v.28, p.141-154, 2003. Disponível em: <http://www.silsoeresearch.org.uk/animal- 
welfare/jeff/humane-slaughter.pdf >. Acesso em: 25 ago. 2010. doi:10.1016/S0144-8609(03)00021-9.

MATOS, E. et al. Effect of harvesting stress and slaughter conditions on selected flesh quality criteria of gilthead seabream (Sparus aurata). Aquaculture, v.305, p.66-72, 2010. Disponível em: <http:// gouwuche.com/science?_ob=MImg\&_imagekey=B6T4D-4YYGGVP$5 \mathrm{~J} \&$ \& cdi $=4972 \&$ \&_user $=4861547$ \&_pii=S 004484 $8610002784 \&$ _orig=browse\&_coverDate $=04 \% 2 \mathrm{~F} 28 \% 2 \mathrm{~F} 2$ $010 \&$ s k $=999999999 \& \mathrm{view}=\mathrm{c} \& \mathrm{wchp}=\mathrm{dGLbVlb}-$ zSkWb\&_valck=1\&md5=3ed00f90cf7b70295eb64d423f6437b1\&ie=/ sdarticle.pdf>. Acesso em: 26 ago. 2010. doi:10.1016/ j.aquaculture.2010.04.020.

MEINERTZ, J.R. et al. Isoeugenol concentrations in rainbow trout (Oncorhynchus mykiss) skin-on fillet tissue after exposure to AQUI-S ${ }^{\mathrm{TM}}$ at different temperatures, durations, and concentrations. Aquaculture, v.254, p.347354, 2006. Disponível em: <http://www.sciencedirect.com/ science?_ob=ArticleURL\&_udi=B 6T4D-4HNYMCK$1 \&$ _user $=687358 \&$ \&coverDate $=04 \% 2 \mathrm{~F} 28 \% 2 \mathrm{~F} 2006 \&$ \&doc $=1$ \&_fmt=high\&_orig=search\&_sort=d\&_docanchor=\&view=c\&_searc $\mathrm{hStrId}=1442321079 \&$ rerunOrigin $=$ google $\&$ acct $=\mathrm{C} 000037$ $899 \& \_$version $=1 \&$ \&urlVersion $=0 \&$ \&userid $=687358 \& \mathrm{md} 5=0 \mathrm{~d} 5 \mathrm{~b} 99 \mathrm{a}$ $5045 \mathrm{cc} 241 \mathrm{ff} 69 \mathrm{e} 5 \mathrm{aaa} 9 \mathrm{cf} 2 \mathrm{f} 4 \mathrm{e}>$. Acesso em: 26 ago. 2010. doi:10.1016/j.aquaculture.2005.09.028.

OLSEN, Y.A. et al. Metomidate anaesthesia in Atlantic salmon, Salmo salar, prevents plasma cortisol increase during stress. Aquaculture, v.134, p.155-168, 1995. Disponível em: <http://www.sciencedirect.com/ science?_ob=ArticleURL\&_udi=B 6T 4D-3Y 45G3Y93\&_user $=687358 \& \_c o v e r D a t e=07 \% 2 F 01 \% 2 F 1995 \& \_r d o c=1 \&$.

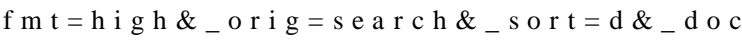
anchor $=\&$ vie w $=$ c \&_searchStrId=1442321683\& - r e r u n O rigi n = g o o g 1 e \& _ a c c t $=$ C 00000 $37899 \&_{\text {_ ver sion }}=1 \&_{\text {_ u r } 1 \text { Versio }}=0 \&_{\text {_ }}$ u serid $=687358 \& \mathrm{md} 5=\mathrm{e} 553 \mathrm{c} 346 \mathrm{e} 606 \mathrm{f} 0 \mathrm{~b} 800 \mathrm{dac} 3530 \mathrm{becb0e} 4>$. Acesso em: 26 ago. 2010. doi:10.1016/0044-8486(95)00008-P.

PICKERING, A.D. et al. Stress responses and disease resistance in salmonid fish: effects of chronic elevation of plasma cortisol. Fish Physiology and Biochemistry, v.7, p.253-258, 1989. Disponível em: <https://springerlink3.metapress.com/content/ $06701 \mathrm{t} 3$ w $57576868 / \mathrm{res}$ ource-secured/ ?target=fulltext.pdf \&sid=yi0c5xqbjpk3pc55npxjgu $45 \&$ sh=www. springerlink.com>. Acesso em: 26 ago. 2010..doi:10.1007/ BF00004714.

RIBAS, L. et al. Comparison of methods for anaesthetizing Senegal sole (Solea senegalensis) before slaughter: Stress responses and final product quality. Aquaculture, v.69, p.250258, 2007. Disponível em: <http://www.sciencedirect.com/ science?_ob=ArticleURL\&_udi=B 6T 4D-4NX2NG1$6 \&$ \&user $=687358 \&$ \&coverDate $=09 \% 2 \mathrm{~F} 14 \% 2 \mathrm{~F} 2007 \&$ \&doc $=1 \&$ _fmt=high\&_orig=search\&_sort=d\&_docanchor $=\&$ view=c\&_searchS trId $=1442330410 \& \_r e r u n O r i g i n=g o o g l e \& \_a c c t=C 000037899 \&$ version $=1 \&$ _urlVersion $=0 \& \_u s e r i d=687358 \& \mathrm{md} 5=\mathrm{e} 6 \mathrm{fb} 48 \mathrm{e} 5262207 \mathrm{e} 9 \mathrm{c} 75$ 149291f38602b>. Acesso em: 26 ago. 2010. doi:10.1016/ j.aquaculture.2007.05.036.

ROTLLANT, J. et al. Pituitary and interrenal function in gilthead sea bream (Sparus aurata L., Teleostei) after handling and confinement stress. General and Comparative Endocrinology, v.121, p.333342, 2001. Disponível em: <http://www.sciencedirect.com/ science?_ob=ArticleURL\&_udi=B6WG0-458NMFJ $4 \mathrm{H} \& \_$user $=687358 \& \_$coverDate $=03 \% 2 \mathrm{~F} 31 \% 2 \mathrm{~F} 2001 \& \_$rdoc $=1 \& \_\mathrm{fmt}=$

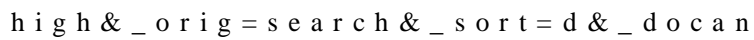
chor $=\& v i$ e w $=$ c \&_se a r ch StrId $=1442336495$ \&_rerunOrigin $=$ google\&_acct $=C 000037899$ \&_version $=1$ \&_urlVersion $=$ $0 \& \_u s e r i d=687358 \& \mathrm{md} 5=51 \mathrm{c} 5 \mathrm{dc} 05 \mathrm{a} 53 \mathrm{f} 9 \mathrm{c} 75 \mathrm{df7} 73036 \mathrm{~b} 0978 \mathrm{eeb} 9>$. Acesso em: 26 ago. 2010. doi:10.1006/gcen.2001.7604.

SAVENIJE, B. et al. Effects of feed deprivation and electrical, gas, and captive needle stunning on early postmortem muscle metabolism and subsequent meat quality. Poultry Science, v.81, p.561-571, 2002. Disponível em: http://ps.fass.org/cgi/ reprint/81/4/561. Acesso em: 25 ago. 2010.

SCHOETTGER, R.A.; JULIN, M. Efficacy of MS-222 as an anesthetic on four salmonids. Fish Control U.S. Department International, v.13, p.1-15, 1967.

SKJERVOLD, P.O. et al. Rigor in Atlantic salmon as affected by crowding stress prior to chilling before slaughter. Aquaculture, v.175, p.93-101, 1999. Disponível em: <http://www.sciencedirect.com/ science?_ob=ArticleURL\&_udi=B6T4D-3 WFN9SY$7 \& \_u s e r=687358 \& \_$coverDate $=04 \% 2 \mathrm{~F} 30 \% 2 \mathrm{~F} 1999$ \&_rdoc $=1 \& \_\mathrm{fm}$ $\mathrm{t}=$ high \&_orig=search\&_sort=d\&_docanchor=\&view $=$ c\&_searchStrId $=1442343610 \&{ }_{-}$r e r u n O ri g i $n=g$ o o gle\&_acct $=$ C000037899\&_version $=1 \&$ _urlVersion $=0 \&$ \&u serid $=687358 \& \mathrm{md} 5=1 \mathrm{~b} 8 \mathrm{e} 057 \mathrm{~d} 3 \mathrm{e} 559 \mathrm{e} 74 \mathrm{edad} 1 \mathrm{fe} 76 \mathrm{f} 588468>$. Acesso em: 26 ago. 2010. doi:10.1016/S0044-8486(99)00037-X.

SKJERVOLD, P.O. et al. Live-chilling and crowding stress before slaughter of Atlantic salmon (Salmo salar). Aquaculture, v.192, p.265-280, 2001. Disponível em: <http://www.sciencedirect.com/ science?_ob=ArticleURL\&_udi=B 6T 4D-4 1 H3 KVPH\&_user $=687358$ \&_coverDate $=01 \% 2 \mathrm{~F} 15 \% 2 \mathrm{~F} 2001$ \&_rdoc $=1$ \&_fmt=high\&_orig=search\&_sort=d\&_docanchor $=\& v i e w=c \& \_s e a r c h$ StrId $=1442356293 \&$ _rerunOrigin $=$ google $\& \_a c c t=C 000037899$ \&_version=1\&_urlVersion=0\&_userid=687358 $\& \mathrm{md} 5=$ eda $8 \mathrm{~b} 718 \mathrm{~d} 4 \mathrm{ed} 3$ 229ba8446a63df5f890>. Acesso em: 26 ago. 2010. doi:10.1016/ S0044-8486(00)00447-6.

SLADKY, K.K. et al. Comparative efficacy of tricaine methanosulfonate and clove oil for use as anesthetics in red pacu (Piaractus brachipomus). American Journal of Veterinary Research, v.62, p.337-342, 2001. Disponivel em: 〈http://www.ncbi.nlm.nih.gov/pubmed/11277197> . Acesso em: 25 ago. 2010.

SLOMAN, K.A. et al. Stress from air emersion fails to alter chloride cell numbers in the gills of rainbow trout. Journal of Fish Biology, v.59, p.186-190, 2001. Disponível em: <http:// onlinelibrary.wiley.com/doi/ $10.1111 /$ j. 1095 8649.2001.tb02351.x/pdf>. Acesso em: 25 ago. 2010. doi:10.1111/ j.1095-8649.2001.tb02351.x.

STEHLY, G.R.; GINGERICH, W.H. Evaluation of Aqui-Sk (efficacy and minimum toxic concentration) as an anaesthetic/ sedative for public aquaculture in the United States. Aquaculture Research, v.30, p.365-372, 1999.

SUMPTER, J.P. et al. Stress-induced elevation on plasma a-MSH and endorphin in brown trout, Salmo trutta L. General and Comparative Endocrinology, v.59, p.257265, 1985. Disponível em: <http://www.sciencedirect.com/ science?_ob=ArticleURL\&_udi=B 6W G0 -4 DVV4S YGC\&_user $=687358 \&$ _coverDate $=06 \% 2 \mathrm{~F} 30 \% 2 \mathrm{~F} 1986 \&$ \&doc $=$ 
$1 \& \_$fmt=high \&_orig=search\&_sort=d\&_docanchor $=\& v i e w=c \&$ _searchStrId $=144236846 \&$ _rerunOrigin $=$ google \&_acct $=$ C0000 37899\&_version=1\&_urlVersion=0\&_userid687358\&md5=e1680c7232c $159 \mathrm{e} 45 \mathrm{be} 3 \mathrm{db} 6 \mathrm{c} 2 \mathrm{~b} 88 \mathrm{ff} 8 \mathrm{e}>$. Acesso em: 26 ago. 2010. doi: $10.1016 / 0016-6480(85) 90377-6$.

US FDA (Food and Drug Administration), 2007. Guidance for Industry: concerns related to the use of clove oil as an anesthetic for fish. Rockville, 2007. (April 24).

US FDA (Food and Drug Administration) Animal \& Veterinary Designations list. June $6^{\text {th }}, 2010$. Acesso em: 25 jun. 2010. Online. Disponível em: <http://www.fda.gov/AnimalVeterinary/
DevelopmentApprovalProcess/MinorUseMinorSpecies/ ucm 125445.htm>.

VELLUTI, A. et al. Inhibitory effect of cinnamon, clove, lemongrass, oregano and palmarose essential oils on growth and fumonisin B1 production by Fusarium proliferatum in maize grain. International Journal of Food Microbiology, v.89, p.145-154, 2003. Disponível em: <http://www.sciencedirect.com/ science?_ob=ArticleURL\&_udi=B6T7K-48FK6VK$8 \&$ \&user $=687358 \&$ \&coverDate $=12 \% 2 \mathrm{~F} 31 \% 2 \mathrm{~F} 2003 \&$ \&doc $=1 \&$ _fmt $=$ high $\&$ orig $=$ search $\&$ _sort $=\mathrm{d} \&$ _docanchor $=\& \mathrm{view}=\mathrm{c} \&$ _a cct $=$ C000037899\&_version $=1 \&$ urlVersion $=0 \&$ \&userid $=687358 \& \mathrm{md} 5=$ 9829792 bbaccefb 3 c604aa4e7bca03e0>. Acesso em: 26 ago. 2010. doi:10.1016/S0168-1605(03)00116-8. 